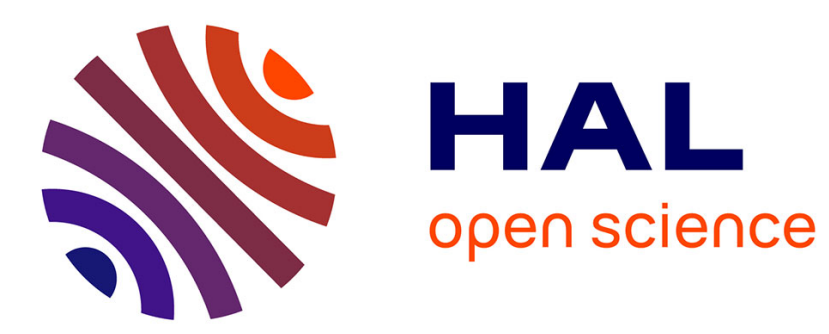

\title{
Context and Contextualisation: Hallmarks of Authentic Spoken English \\ Adam Wilson
}

\section{To cite this version:}

Adam Wilson. Context and Contextualisation: Hallmarks of Authentic Spoken English. Recherche et pratiques pédagogiques en langues de spécialité - Cahiers de l'APLIUT, 2021, Anglais oral: enjeux théoriques et pratique(s) authentique(s), 40 (1), 10.4000/apliut.8547 . hal-03131123

\section{HAL Id: hal-03131123 \\ https://hal.univ-lorraine.fr/hal-03131123}

Submitted on 4 Feb 2021

HAL is a multi-disciplinary open access archive for the deposit and dissemination of scientific research documents, whether they are published or not. The documents may come from teaching and research institutions in France or abroad, or from public or private research centers.
L'archive ouverte pluridisciplinaire HAL, est destinée au dépôt et à la diffusion de documents scientifiques de niveau recherche, publiés ou non, émanant des établissements d'enseignement et de recherche français ou étrangers, des laboratoires publics ou privés. 
Recherche et pratiques pédagogiques en langues de spécialité

Cahiers de l'Apliut

Vol. $40 \mathrm{~N}^{\circ} 1 \mid 2021$

Anglais oral : enjeux théoriques et pratique(s) authentique(s)

\section{Context and Contextualisation: Hallmarks of} Authentic Spoken English

Contexte et contextualisation: marques de fabrique de l'anglais oral authentique

Adam Wilson

\section{OpenEdition \\ Journals}

Electronic version

URL: http://journals.openedition.org/apliut/8547

ISSN: 2119-5242

Publisher

APLIUT

This text was automatically generated on 31 January 2021. 


\title{
Context and Contextualisation: Hallmarks of Authentic Spoken English
}

Contexte et contextualisation: marques de fabrique de l'anglais oral authentique

\author{
Adam Wilson
}

\section{Introduction: language and authenticity}

1 If one opens more or less any dictionary of the English language, the definition given for "authentic" will most likely make reference to something "real" or "genuine", that is, not "fake", "false" or "copied". When used to qualify language, "authentic" is almost always indissociable from the figure of the native speaker: native speakers are seen as the unique holders of the ability to produce "real", "genuine" or "not fake" language. Thus, researching, teaching or learning "authentic" English (as with any language) would equate to researching, teaching or learning English as produced by native speakers.

2 Following this definition, one might be tempted to qualify the English used in the example below - an extract from an interaction between two speakers (CF1 and T1) - as "inauthentic":

CF1: bonjour? ${ }^{1}$

[...]

T1: hello

CF1: bonjour

T1: i'm looking for a plan (.) er (.) a:nd (.) for a recommendation of the highlights here o- (.) something that (.) i can do also with kids?

(CF1 opens a map on the counter)

CF1: so (.) we are here (.) er (.) on the right part of the port (.) this part (.) it's the old town of marseille there is different (.) historic sights (.) errr (.) how- how old (.) 
are (.) th- $=$

T1: =errm (.) from (.) eleven to four yeah=

CF1: $=$ ok $=$

$\mathrm{T} 1:=$ eleven eight and four yeah

3 First of all, aside from the exchange of greetings, there are certain aspects in the language of both speakers that may lead us to qualify the English as non-native, such as T1's non-standard use of "plan" or CF1's use of a double subject with both "this part" and "it's". In fact, this extract is taken from an interaction between a German-speaking Swiss (T1) and a native French-speaker (CF1). According to the definition of authenticity given above, this clear identification of two non-native speakers might lead the English being used to be qualified as "inauthentic" and, it might be argued, somewhat inferior as a reference point for "real" English use.

4 The position adopted here is that this (extremely prevalent) conflation of nativeness and authenticity is not only questionable but also damaging and dangerous. To be clear, there is no intrinsic reason as to why the productions of a certain group of speakers may be classified as more authentic, or real, than those of another. Rather, this link is ideological in nature (Lowe and Pinner). Through a variety of processes, native speakers have been, and continue to be, positioned as the sole group with the necessary linguistic and cultural characteristics to be considered as a legitimate authority in terms of how language should sound, look and be used (Creese et al.).

5 Discussion of, and resistance to, these ideological dynamics is nothing new and many authors have pointed out their far-reaching, destructive consequences. For instance, Piller (120) shows how the "idealization" of native speakers promotes a worldview which is inherently biased towards both monolingualism and standard(ised) languages. For Pennycook, dividing the world into native and non-native speakers of English sustains colonial distinctions of the Self and Other, positioning the native speaker as "not merely a supposedly better teacher of English but also someone endowed with superior knowledge about the world" (Pennycook 156). This echoes both what Phillipson (193) calls the "native speaker tenet" and the notion of "native-speakerism" (Holliday), ideas that native speakers from traditionally English-speaking countries are the best models of English and thus the best models, and teachers, of the language. Clearly, these ideological dynamics are intrinsically intertwined with questions of social hierarchisation, exclusion and dominance in that they cast the native speaker as a superior, monolingual Self and position non-natives as inferior, deficient Others. The native speaker is thus considered as an idealised target against which non-natives are measured - and with whom they are potentially in competition professionally - and against which they invariably fall short.

Clearly then, the "nativeness as authenticity" ideology is extremely problematic and, potentially, damaging. In the hope of proposing a first step towards an alternative vision of authenticity which could help in going beyond this native speaker hegemony, this article aims to foreground other features of spoken English that could be considered to index authenticity.

7 In this respect, the above example illustrates some of the complexities involved in identifying authenticity in language use. While some might be tempted to qualify aspects of the English use as inauthentic, there are clearly elements present in the extract which suggest that the exchange has an authentic quality. For example, there 
are features of spontaneous talk-in-interaction that do not appear in rehearsed nonnaturally occurring speech: hesitations, repetitions, false-starts, heavy use of deixis, coconstruction of utterances and so on. Beyond this, there are also thematised (explicitly mentioned) elements that aid in the identification of the situation, so much so that with only this small sample of dialogue, it is easy to recognise the context. In this example, the mention of toponyms, the use of and reference to material supports (a map), discourse that one might attribute to this particular context and certain elements pertaining to the structure of the interaction make it easy to identify a tourist information encounter ${ }^{2}$.

8 So, while many may not define the English used by these speakers as "authentic", the interaction itself is likely to be classed as such as it is clear that it is not staged, elicited or otherwise false. This is identifiable thanks to the presence of the linguistic markers that have just been highlighted, helping us recognise a naturally-occurring (not faked) social situation. This article puts forward the argument that these markers - visible traces of the link between language and context - constitute the defining hallmark of authentic language use. More specifically, this article aims to show how the process of co-constructing meaning in interaction, and more precisely the phenomenon of contextualisation involved in this process, are key features of any authentic language use, be it language as used by native speakers or non-native speakers.

While the importance of contextualisation and other aspects of the co-construction of meaning are widely accepted by researchers and teachers as central to language use, positioning them as central to the notion of authenticity could help in overcoming the potentially damaging dominance of the native-speaker models mentioned above. The primary aim of this contribution is to open dialogue between researchers and teachers with an interest in the English language by introducing theoretical and methodological elements which are perhaps less well-known in the field, at least in the French context. This will be done by addressing the following research questions:

- How does contextualisation relate to the authenticity of spoken English (or indeed any other language)?

- How does the creation of teaching and/or research materials lead to a form of decontextualization and what are the effects of this process?

- How can decontextualization be reduced and/or reversed?

10 In order to answer these questions, this article is based around analysis of the example used in the introduction. The following section briefly sets out the methodological and theoretical underpinnings of this study before elements of the theoretical framework and analysis are combined as the above questions are addressed in turn. Firstly, it is shown how contextualisation can be considered a key part of authentic language practices. Secondly, the effects of the necessary decontextualization of language in the creation of research and teaching materials are explored. Thirdly, a look at different ways to recontextualise data is proposed. Finally, some wider repercussions for teaching and research are briefly discussed.

\section{Methodological and theoretical frameworks}

11 The example used in the introduction to this article is an extract taken from recordings made during ethnographic fieldwork at the Tourist office of Marseille (France) that formed the basis of my $\mathrm{PhD}$ research (Wilson). Generally speaking, my research 
approach is characterised by this type of ethnographic fieldwork, often comprising long-term, in situ observation, interviewing, document collection and the recording of spontaneous, naturally occurring interactions that take place between the social actors present in the social contexts I study. In making such recordings, I strive to collect the most "ecological" data possible (Tellier), that is, data from situations which are not staged, provoked or otherwise managed by the researcher, but rather encounters which take place spontaneously in social life.

The reason for this insistence on ecological data is intrinsically linked to the theoretical approach used in my research. Broadly speaking, my research sits at the crossroads of critical sociolinguistics (see Heller), interaction or conversation analysis (see Traverso, "L'analyse") and linguistic anthropology (see Hymes, "Models"). Though distinct disciplines, they share a number of common theoretical and methodological underpinnings and their combination is closely related to the sub-discipline that goes by the name of "interactional sociolinguistics" (see Gumperz). In general, researchers that situate themselves within these theoretical frameworks aim to study the interactions between language use and social life. On the one hand, they aim to explore the influence of social context(s) on language form and use. On the other, they examine how language use contributes actively to the elaboration of social contexts and social life more generally. Interactional sociolinguists are particularly interested in how language and social life are linked in the activity of social interaction, seen as the nexus at which social worlds are elaborated linguistically in real time by social actors. In order to undertake this scientific enterprise, researchers adopt a holistic approach, aiming to describe context, language and language-in-context. This requires linguistic data to be observed in its real-world, naturally occurring social setting.

Ecological data is inherently authentic then, captured in a real, unstaged, occurrence of human interaction. Such data provides an excellent opportunity to explore questions of authenticity and language use.

\section{Contextualisation as authenticity}

As mentioned previously, the extract used in the introduction to this article reproduced below in order to facilitate the reading experience - seems authentic to us for a number of different reasons. One of these reasons is the existence of linguistic traces of contextualisation that signal to us that the interaction took place in a real or authentic context. This section explores how contextualisation and, by extension, context itself are key to the authenticity of spoken English, or any spoken language.

In order to explore the idea of contextualisation in detail, it is necessary to take a quick look at what happens in social interaction at a basic level. In any interaction, humans involve themselves in a process of co-constructing meaning by combining their communicative resources in order to make sense together. One of the key ways in which speakers overcome the extreme complexity of this process is through the "cooperative principle" (Grice): speakers leave allowances for the fact that other speakers leave many things unsaid - as anyone does when communicating - and "fill in the blanks" through inference, often relying heavily upon contextual elements. In a related process, when interacting, speakers are said to find, and maintain, "common ground" (Stalnaker), or agreement on what is going on, the action taking place, the stakes in play and the meaning that is being made together. Finding and maintaining 
common ground is essential to ensuring smooth interaction and requires a significant amount of inference and cooperation. Much of this invokes contextual elements. Contextualisation is thus key to the meaning-making process, as can be seen in the example reproduced below.



In the extract, it is clear that the participants have found the common ground of a tourist information encounter: they agree on what is taking place in the interaction and how the exchange should proceed. Of course, the geographical and physical setting - the Tourist Office of Marseille - goes a long way to helping the speakers along this road. However, using language which might be expected in this context also contributes to the elaboration of common ground. For example, the interlocutors contribute to a live contextualisation of the interaction as one which takes place in a context of tourism by thematising elements such as maps, (tourist) highlights or suggestions of certain places to visit and things to do. Indeed, the ways in which T1 and CF1 thematise these key pieces of information also contribute to the live contextualisation of their own identities (in this situation) as a tourist and a tourist advisor respectively. Going further, some aspects of the structure of the interaction itself also contribute to the co-construction of meaning and the elaboration of common ground. The greetings are followed immediately by a request made by T1. In a different context, such as a family gathering for instance, this chain of sequences might be highly unexpected as more "small talk" might be expected. However, in this case, immediately following the opening of the interaction with a request is ratified and nonmarked by CF1. Such interactional structure is very common to service encounters, which develop a "routine" quality (Traverso, "Interactions") such as this one. In short then, the two speakers give off different linguistic and interactional "clues" that contribute to creating the common ground of a tourist information encounter. The ratification of these clues, by accepting and reacting (positively) to them, also helps in building common ground and keeping it stable. This is the co-construction of meaning. These "clues" are not simply a linguistic manifestation of context in the interaction, they play an active role in the elaboration of said context. These markers, or clues, are what Gumperz terms "contextualisation cues" (Gumperz 131).

Gumperz defines contextualisation cues as having two main roles. Firstly, they help participants identify the context in which they are interacting. This role can be linked to the idea of indexicality (Silverstein, "Shifters"), according to which certain linguistic 
forms or practices become markers which point to, or "index", social identities or other elements of social context. In this case, the immediate positioning of a request after a sequence of greetings might be considered to index, or point to, a service interaction. These markers often tend to occur in recurring patterns, or "orders of indexicality" (Silverstein, "Indexical Order"). Over time, these markers come together to form a stable set of linguistic forms and practices that become linked to a given context. This leads to the development of a "register" through a process of "enregisterment" (Agha). These registers and related indexical relationships are learnt throughout life in a process of socialisation. This is done both first hand, through the interactional history (Vion) of an individual, as well as through the observation of language practices on television, in film or during educational experiences. It is thus easy to see how an inextricable link between language and social context becomes deeply engrained in human behaviour, allowing us to identify context, in part, thanks to linguistic contextualisation cues.

This profound link between language and context is central to the second role played by contextualisation cues. As well as aiding individuals to identify the contexts in which they find themselves, contextualisation cues also allow speakers to contribute to actively co-creating social context through language. All linguistic production is conditioned or, at the very least, in some way influenced, by its context of production. In any given situation, speakers have a choice: they can either behave (linguistically) in the way that is seen to be expected of them, or they can refuse this contextual conditioning. Either way, speakers contribute, through their linguistic behaviour, to the elaboration of the situation itself. Simply put, a speaker who conforms to the expected patterns of language use one might expect to observe in a tourist situation contributes in turn to the elaboration of this same context. Conversely, refusal to follow the expected schemas of language practices will likely result either in the elaboration of an alternative social context or a situation in which other interlocutors seek to glean social meaning from this departure from sociolinguistic norms. Using contextualisation cues is a key aspect of this process: speakers help to create a given social context by marking it as such linguistically.

Language and context then become heavily intertwined in situations of authentic spoken interaction. This bond between language and context sits at the heart of the notion of pratiques langagières [language practices] (Boutet), conceptualising the fact that all linguistic practices are influenced by their context of production, but are also constitutive of the same context. In other words, "[1]anguage is context, it is the architecture of social behaviour itself" (Blommaert and Jie 7).

Language and context cannot thus be separated, they exist as one, with context leaving traces in the language and language contributing to the social situation. This relationship is central to any instance of authentic spoken language. Without the traces of this relationship, language seems "fake", "false" or otherwise "inauthentic". The example discussed here concerns spontaneous spoken interaction but the same principle can be applied to any authentic use of language (even heavily prepared speeches (or, indeed, pieces of written language) contain traces of contextualisation). All authentic language is produced in context, and this context leaves a mark upon the linguistic fabric in the form of contextualisation. Contextualisation thus stands out as a marker par excellence of authenticity in language use. 


\section{Decontextualization in the development of teaching and research materials}

21 The fact that contextualisation constitutes a key feature of authentic language use is potentially problematic when it comes to reflecting on the creation of research and teaching materials. In almost all cases, the development of such materials requires a certain degree of decontextualization, so that the language can be used - and thus recontextualised - in another setting to that of its natural occurrence. This section aims to explore this process and its effects.

22 Firstly, it is worth pointing out that some (perhaps, a lot of) teaching and research material is created ex nihilo. These materials, elaborated from scratch, are necessarily "inauthentic" in that they have been created for the purpose of teaching or research, rather than being an example of naturally occurring, ecological language use. It could be argued that these materials are often construed as being "inauthentic" by both teachers and learners ${ }^{3}$. It could also be argued that a large part of this feeling of inauthenticity comes from the fact that there is often little trace of contextualisation. Sometimes, significant efforts are made by teachers or researchers to make their examples more "authentic" by giving them some (imagined) context. However, generally speaking, the language is still recognisable as inauthentic, in large part due to the absence of contextualisation cues (among, one imagines, a number of other tell-tale elements).

23 As well as these ex nihilo examples, teachers and researchers also work extensively with examples of language taken from the real world. These authentic examples of language must be extracted from their context of utterance and this leads to a necessary process of decomplexification. In research, at least from the perspective of a sociolinguistic ethnographer, one would ideally have access to all elements of language form, language use and context in order to conduct the most comprehensive analysis possible. Of course, this is almost impossible. The only way in which this could be undertaken is live, within the context of language production. However, few and far between are the researchers who can undertake detailed analyses in real-time. Thus, linguistic (and other) data need to be taken from their context of use and somehow stored, before being exploited at a later date, in a wholly new context.

This undertaking inevitably leads to the loss of data complexity. To take but a simple example, if the only type of recording available is that of audio recording, almost all multimodal aspects of the situation - absolutely central to the co-construction of meaning - are lost. Similarly, the transformation of spoken oral data to transcribed written data leads to the loss of huge amounts of prosodic and other suprasegmental detail. In any situation, and whatever the technology, time and resources available to the researcher, the extraction of data leads to a huge loss of contextual information. Language can never be placed back into its initial, natural context of use. As such, the decontextualization of language in the preparation of research materials necessarily engenders the loss, or deliberate removal, of some aspects of authentic language.

The above scenario refers to research but it is easy to draw parallels with the creation of teaching materials, a process in which the same decontextualization and decomplexification take place. In both cases, removing language from its natural context of occurrence leads to the disappearance of contextual elements and thus to 
difficulties in accessing certain aspects of linguistic contextualisation. This is then potentially problematic if this contextualisation is to be seen as a decisive factor in what might be considered an authentic example of spoken language.

\section{Recontextualization in the development of teaching and research materials}

Given that researchers in ethnographic sociolinguistics (and related disciplines) go to a lot of effort to reduce context loss or account for the elements lost during decontextualization, it could be argued that tools from these disciplines could be useful in addressing the problems of decontextualization highlighted above.

Many researchers working in these disciplines share a vision of language not as (primarily) a system of interlocking linguistic levels independent from social behaviour but as a set of resources that humans use in order to undertake social actions. The focus of research in these fields thus centres less on the way in which language works as a system in and of itself and more on the way in which it functions within society. Researchers concentrate on what people actually do with language and the social function that linguistic forms and practices have. In the context of research, this focus somewhat reinstates elements of contextualisation thanks to the link between language use and its social context being placed centre stage in the analysis process.

Something similar could be applied in the context of teaching: seeing language first and foremost not as a complex set of linguistic forms that must be acquired but rather as a set of resources with which humans accomplish (social) actions. It is clear that the focus on such issues is becoming more prevalent in educational settings around the world. For instance, action-based, skill-based and problem-based approaches which move in this direction are currently very much in vogue - not least in the CEFRL, the programme of the French Ministry of Education and a multitude of recent textbooks.

However, while this type of approach is becoming more common in education, it could be argued that such practices, and the linguistic forms, uses and skills developed within them, are rarely mentioned in relation to the authenticity of spoken language. In many educational contexts, authenticity would still seem to exclusively equate to "sounding like a native speaker"4. Of course, one can accomplish acts while sounding like (or indeed being) a native speaker. However, positioning language as a social practice above all else, and positioning this language as authentic precisely because it is a social practice, might contribute to the label of authenticity being widened to "language used to do things", rather than being exclusively reserved for linguistic productions that resemble those of a native speaker.

The theoretical conception of language as a set of resources opens doors to other possible solutions which are perhaps more methodological in nature. As mentioned previously, sociolinguistic ethnographers, and researchers from related disciplines, invest considerable time and effort into collecting data which is naturally occurring. This kind of ecological data is very seldom used in its raw form in teaching. This is understandable, given the fact that such recordings are often unsuitable for the classroom (due to issues such as background noise, etc.). Having said that, there are numerous examples of teaching materials (e.g. Cauldwell; Hancock and McDonald) that show how this kind of data can be successfully incorporated. However, in the vast 
majority of cases, the data is used for activities that themselves do not necessarily seek to be authentic co-constructions of meaning, often focusing on developing one particular individual skill (listening, speaking, etc.). This is by no means a criticism of these resources, which can be highly effective in developing the skills they target. However, in terms of authenticity, while the data may be ecological, the way in which it is used still leads to it being heavily decontextualized.

Beyond using ecological data as a pedagogical support for other activities, such data could be used as a basis for teaching materials aimed specifically at developing skills related to language viewed as a social practice. The methodological and theoretical underpinnings of sociolinguistic ethnography could come in extremely useful in such a scenario. Through their focus on ecological data, researchers in the field aim to provide the most detailed and comprehensive descriptions of speech situations as possible. Sociolinguistic ethnographers try to understand how language works in the real world, collecting as much of that real-world data as possible, from as many sources as possible, linguistic or otherwise. Since the birth of the field, tools have been developed in order to help comprehensively document multiple aspects of speech situations. Perhaps the classic example is the "SPEAKING" model introduced by Dell Hymes (Hymes, "Models"), which sets out a framework of the principal elements that need to be taken into account when analysing a speech situation: setting (or scene), participants, ends, act sequence, key, instrumentalities, norms and genre ${ }^{5}$. Since this seminal work, there have been continual developments in the field that add to researchers' abilities to document the complexity of speech situations (see, for example, Blommaert and Jie; Copland and Creese).

Methodological developments which give a global, detailed overview of communication situations have thus progressively allowed researchers to contextualise, or recontextualise, the language practices they study in an increasingly comprehensive manner, allowing key linguistic and contextual elements to be identified in any situation. The tools used could be adapted and flipped around, used not to describe existing contexts but to create, or recreate, new contexts that would allow language practices to be "resituated" in an educational setting. This might allow teaching practices to explore new forms of authentic spoken English use, by creating ultrarealistic settings in which extensive contextualisation - a hallmark of authenticity would be required. For example, to return to the recurring example used in this article, the ethnographic work, linguistic data and analyses undertaken during my $\mathrm{PhD}$ project could form the basis for the development of hyper-realistic scenarios in a context of tourist service encounters.

Of course, this does not mean that all teachers need to become ethnographers, or that only ethnographers are equipped to teach authentic English. Rather, increased communication between the worlds of research and teaching could lead to ethnographic studies being used as a realistic, or authentic, basis for teaching materials. A huge amount of detailed ethnographic sociolinguistic work has been undertaken in a vast array of contexts: international business meetings (Mondada and Nussbaum), urban marketplaces (Pennycook and Otsuji) and international call centres (Woydack), to name but three examples. Such work could form the basis for teaching materials modelled on what actually happens in context, both linguistically or more generally. This could lead to the development of research-led teaching activities such as role plays, serious games, etc. Given the breadth of research, this could be applied to 
a huge number of situations, pushing students to experience and produce "authentic" that is contextualised - English.

To my knowledge, there are little to no examples of such undertakings. While introducing ethnography into a student's learning experience has been explored (see Roberts et al.), there has been little discussion around using existing ethnographic studies to inform teaching. Thus, greater dialogue between researchers from the fields mentioned above and teachers and researchers perhaps less familiar with the approach could prove extremely fruitful in this respect.

\section{Wider repercussions}

So far, this article has argued that contextualisation, and context, sit at the heart of authenticity in spoken English. The previous section explored how aspects of contextualisation that are lost in the creation of teaching or research materials could be "reinstated" to a certain degree. Beyond introducing more authentic language forms and uses into the classroom, this could also have further-reaching repercussions.

\subsection{Developing communicative competence}

In almost all situations linked to teaching spoken English, teachers and students share the common principal aim of developing students' communicative competence (Hymes, "On Communicative"). This involves developing not just grammatical knowledge but also knowledge on how language is used appropriately in context. One key aspect of this communicative competence is mastery of contextualisation cues, both in terms of their production and interpretation. Clearly, teaching materials developed with contextualisation at the forefront of the creator's mind are likely to be well placed in helping students to develop these skills. Such materials could add to the growing body of work aimed at elaborating pedagogical material linked to developing skills involved in the co-construction of meaning and in social interaction more generally (Manoïlov and Oursel).

Successfully navigating life's situations of communication involves developing communicative competence in a wide range of different contexts, each with their own norms, rules and registers. Dealing with this array of situations is of course something that all students of any language aspire to be able to do in their target language, and something that all teachers aim to help their students develop. One of the ways in which this is done is through exposure to a diversity of contexts. The approach advocated for in this article could contribute to such exposure by facilitating the elaboration of realistic teaching materials that echo the real thing to such an extent that contextualisation cues become part and parcel of pedagogical activities. For some students, recognising and using contextualisation cues is also something that could be taught explicitly and theoretically, paving the way for the development of transferable skills related to contextualisation. In any case, the wealth of ethnographic research means that such materials could be developed for a diverse array of contexts, something which could be beneficial to all students, but perhaps especially to those not fortunate enough to come into contact with a wide range of different contexts of communication in the course of their lives. 


\subsection{Going beyond native-speakerism} English cited above, it would seem to remain general practice for English to be taught through native-speaker based models ${ }^{6}$. For instance, while exceptions do exist, English phonology is often taught and, more importantly, evaluated more or less exclusively through Received Pronunciation and/or General American. Of course, other varieties (Australian, Irish, etc.) are sometimes included, but they tend to play a marginal role in any English language course. Furthermore, the varieties that do get included tend to be those linked to the people mentioned above: those who hail from (and conform to ethnic stereotypes of people from) traditionally English-speaking countries in the global North. Other varieties of English, such as those found in the global South, those used by speakers from minority ethnic groups or those used by non-natives, are very rarely addressed, unless they are being used as an exceptional example to show just how widespread, diverse and potentially "exotic", English can be. Rather than giving value to these varieties, it could be argued that, as well as having colonial undertones, such practices consign them to the periphery, anchoring them well away from the central, "authentic" models used for English teaching. It is clear that these questions of native and non-native approaches to authentic English teaching are intrinsically wrapped up in "raciolinguistic" ideologies (Rosa and Flores), something which may constitute a fruitful avenue for further research. research) based on native-speaker ideologies is still widespread. As explored in the opening sections of this article, these ideologies exclude the vast numerical majority of English speakers, positioning their language and, by extension, themselves as "inauthentic", and thus inherently inferior Others when compared to natives. The potentially damaging effects of this are clear to see in terms of the potential for social, institutional, professional and political exclusion and inequality.

The arguments put forward in this article promote an alternative conception of authenticity that aims to move away from this dangerous ideological link to nativeness: authenticity measured by focusing on the social functions for which language is used, how (native and/or non-native) speakers use it in practice in the real world, and how this usage leaves traces in language that show it to be authentic. Viewed in this way, arguably the most common use of English, as a lingua franca, becomes as authentic as the English used by native speakers. There is nothing "fake" about the way in which English is used, irrespective of the form it takes, and irrespective of who is doing the using. In this respect, "authentic" English should not be a badge reserved for only the language of an elite native speaker minority, but rather a blazon brandished by the language of anyone, anywhere - native or non-native (if such a distinction can be 
considered to remain pertinent) - who draws upon the resources of English in the course of their social life ${ }^{7}$.

Viewing authenticity in this way would represent a relatively sizeable shift in language ideologies. In turn, it would call into question multitudes of linguistic and social hierarchies - not to mention a global language-learning industry - built upon the idea that native speakers hold the key to linguistic authenticity. The chances of such a viewpoint catching on are thus slim. However, it could be argued that moving the conception of authenticity away from the form-based native speaker model towards a function-based conception like the one outlined here might improve our understanding of language and enhance our students' learning, as well as counteract some of the negative effects, both symbolic and (very) real, of the "native speaker as authentic" ideology.

\section{Conclusion}

This article set out to explore how contextualisation relates to the authenticity of spoken English and spoken language more generally. First of all, it showed how contextualisation - the complex interplay between language and context - is one of the defining hallmarks of authentic language use in that it is present in language used in any real, or authentic, setting. Secondly, the article explored how the decontextualization of language involved in the creation of teaching and research materials leads to a decomplexification of data and to the loss of elements of contextualisation, giving the language in these materials an "inauthentic" character. Following this, it was suggested that the application of some of the theoretical and methodological underpinnings of sociolinguistic ethnography and related disciplines could help researchers and teachers better contextualise (or recontextualise) research and teaching materials, thus rendering the language more akin to its authentic counterpart. All in all, contextualisation, and context, were shown to be markers of authenticity in spoken English. Finally, it was suggested that conceiving of authenticity in this way might have two major benefits: a positive effect on the development of students' communicative competence in an educational setting and the possibility of moving beyond the exclusive "native speaker as authentic" paradigm in both teaching and research.

In my view, this final point is the most important. Clearly, conceiving of the (often imaginary) productions of a native speaker as "authentic" and, in contrast, those of a non-native speaker as "inauthentic", is just one way in which authenticity in language can be conceptualised. As discussed throughout this article, this way of thinking is extremely damaging. "Authenticity" quickly becomes synonymous with "acceptability" and it is not difficult to see how "inauthentic" - that is, non-native - English (speakers) become viewed as "unacceptable". Such judgements can have profound effects on those concerned. Shifting the focus of the notion of authenticity away from language as used by the native speaker and towards language as used in social life goes some way to counteracting this negative ideology. It opens up possibilities of viewing language use that traditionally falls outside judgements of "authenticity" (and thus "acceptability") as authentic for the purposes of both teaching and research. It could be argued that this is a win-win situation, ideologically empowering speakers of formerly marginalised varieties of English while in no way disempowering speakers of native varieties. Indeed, 
these groups of speakers are placed on an equal pedestal of authenticity: they are all purveyors of authentic English because they are all real-life users of it. Positioning authentic English as English used as a real social practice is thus a way of giving English back to the people who use it the most.

\section{BIBLIOGRAPHY}

Agha, Asif. “The Social Life of Cultural Value.” Language \& Communication, vol. 23, no. 3-4, July 2003, pp. 231-273.

Blommaert, Jan, and Dong Jie. Ethnographic Fieldwork. A Beginner's Guide. Multilingual Matters, 2010.

Boutet, Josiane. "Pratiques langagières." Dictionnaire d'analyse du discours, edited by Patrick Charaudeau and Dominique Maingueneau, Seuil, 2002, pp. 458-460.

Cauldwell, Richard. A Syllabus for Listening: Decoding. Speech in action, 2018.

Copland, Fiona, and Angela Creese. Linguistic Ethnography: Collecting, Analysing and Presenting Data. SAGE, 2015.

Creese, Angela, et al. "The Ideal 'Native Speaker' Teacher: Negotiating Authenticity and Legitimacy in the Language Classroom.” The Modern Language Journal, vol. 98, no. 4, 2014, pp. 937-951.

Grice, H. Paul. "Logic and Conversation." Syntax and Semantics, Volume 3: Speech Acts, edited by Peter Cole and Jerry L. Morgan, Academic Press, 1975, pp. 41-58.

Gumperz, John J. Discourse Strategies. Cambridge University Press, 1982.

Hancock, Mark, and Annie McDonald. Authentic Listening Resource Pack: Bridging the Gap to Real-World Listening. Klett Sprachen GmbH, 2017.

Heller, Monica. Éléments d'une sociolinguistique critique. Didier France, 2003.

Hymes, Dell H. "Models of the Interaction of Language and Social Life." Directions in

Sociolinguistics: The Ethnography of Communication, edited by John Gumperz and Dell Hymes, WileyBlackwell, 1986, pp. 35-71.

---. “On Communicative Competence." Sociolinguistics: Selected Readings, edited by J.B. Pride and Janet Holmes, Penguin, 1972, pp. 269-293.

Jenkins, Jennifer. The Phonology of English as an International Language. Oxford University Press, 2000.

Leitner, Gerhard. "English as a Pluricentric Language." Pluricentric Languages: Differing Norms in Different Nations, edited by Michael Clyne, De Gruyter Mouton, 1991, pp. 178-237.

Lowe, Robert J., and Richard Pinner. "Finding the Connections between Native-Speakerism and Authenticity." Applied Linguistics Review, vol. 7, no. 1, 2016, pp. 27-52.

Manoïlov, Pascale, and Elodie Oursel. "Analyse des interactions et didactique des langues : tour d'horizon des relations." Linx, vol. 79, 2019. 
Mondada, Lorenza, and Luci Nussbaum. Interactions cosmopolites : L'organisation de la participation plurilingue. Lambert-Lucas, 2012.

Pennycook, Alastair. English and the Discourses of Colonialism. Routledge, 1998.

Pennycook, Alastair, and Emi Otsuji. Metrolingualism: Language in the City. Routledge, 2015.

Piller, Ingrid. “Who, If Anyone, Is a Native Speaker?” Anglistik: Mitteilungen Des Verbandes Deutscher Anglisten, vol. 12, 2001, pp. 109-121.

Roberts, Celia, et al. Language Learners as Ethnographers. Multilingual Matters, 2001.

Rosa, Jonathan, and Nelson Flores. "Unsettling Race and Language: Toward a Raciolinguistic Perspective." Language in Society, vol. 46, no. 5, 2017, pp. 621-647.

Seidlhofer, Barbara. Understanding English as a Lingua Franca. Oxford University Press, 2011. Silverstein, Michael. “Indexical Order and the Dialectics of Sociolinguistic Life." Language \& Communication, vol. 23, no. 3, 2003, pp. 193-229.

---. "Shifters, Linguistic Categories, and Cultural Description." Meaning in Anthropology, edited by Keith H. Basso and Henry A. Selby, 1976, pp. 1-55.

Stalnaker, Robert. “Common Ground.” Linguistics and Philosophy, vol. 25, no. 5-6, 2002, pp. 701-721.

Tellier, Marion. "Quelques orientations méthodologiques pour étudier la gestuelle dans des corpus spontanés et semi-contrôlés." Discours. Revue de linguistique, psycholinguistique et informatique. A journal of linguistics, psycholinguistics and computational linguistics, no. 15, 2014.

Traverso, Véronique. "Interactions ordinaires dans les petits commerces : éléments pour une comparaison interculturelle.” Langage et société, no. 95, 2001, pp. 5-31.

---. L'analyse des conversations. 2nd ed., Armand Colin, 2007.

Vion, Robert. La communication verbale, Analyse des interactions. Hachette, 1992.

Wilson, Adam. Dynamiques sociolinguistiques de la globalisation : L'exemple de l'office du tourisme de Marseille. Unpublished PhD thesis, Aix-Marseille Université, 2016.

Woydack, Johanna. Linguistic Ethnography of a Multilingual Call Center: London Calling. Palgrave Macmillan, 2019.

\section{APPENDIXES}

\section{Appendix - Transcription Conventions}

(.) Pause

a: Lengthened phoneme

? Rising intonation

a- False start/self-interruption

(text) Researcher comments

= Turn immediately follows preceding turn 


\section{NOTES}

1. Transcription conventions can be found at the end of this article.

2. The way in which these elements help us to identify the context will be explored later in this article, but what is important to note here is that they signal to us that the interaction is in some way real or authentic.

3. Of course, this is not necessarily problematic, some teaching and research scenarios actively benefit from the use of linguistic examples that are clearly not authentic or representative of language as used in the real world.

4. It should be pointed out that this conclusion is not the product of any systematic research but rather based on anecdotal evidence from teachers, students and pupils as well as my own observations.

5. Space constraints preclude detailed explanation or discussion of these elements but see (Hymes, "Models") for an accessible and detailed introduction.

6. Once again, this observation, and the ones that follow, are based on first-hand experience of various French university contexts, as well as anecdotal evidence from others in the field, rather than being a result of any systematic research.

7. It should probably be pointed out here that I am not suggesting that all grammars, reference works, learning programmes or educational materials based on native speaker English should immediately be deemed worthless. There are undoubtedly myriad reasons why native speaker models make at least a good starting point for many teaching or research endeavours. The point I am trying to raise here is that the native-speaker model is but one model of English of many that exist - especially given English's global status - and that it is no more, or less, "authentic" than these other models.

\section{ABSTRACTS}

When speaking of language, "authenticity" is almost always indissociable from the figure of the native speaker: native English speakers are seen as the unique holders of the ability to produce "genuine" English. In an effort to move past this harmful ideological positioning, this article sets out the case for another marker to be taken as a benchmark for linguistic authenticity: contextualisation. First, it is shown how contextualisation - the complex interplay between language and context - can be considered as a hallmark of authenticity. Following this, the creation of teaching and research materials is shown to engender decontextualization of linguistic data, leading to the loss of elements of contextualisation. Some theoretical and methodological remedies to this situation are explored. Finally, this conception of authenticity is shown to have benefits in terms of developing students' communicative competence as well as moving beyond the exclusive "native speaker as authentic" ideological paradigm.

En ce qui concerne le langage, la notion d'" authenticité » est souvent indissociable du locuteur natif : le locuteur natif d'anglais est considéré comme le seul individu qui puisse produire de « vrais » exemples d'anglais oral. Dans le but d'aller au-delà de ce positionnement idéologique contreproductif, cet article met en avant un autre phénomène qui pourrait être considéré comme un marqueur d'authenticité linguistique: la contextualisation. Dans un premier temps, nous montrons en quoi la contextualisation - l'interaction complexe entre langage et contexte - peut 
être vue comme un repère d'authenticité. Ensuite nous démontrons en quoi l'élaboration de supports d'enseignement et de recherche peut créer une perte de certains éléments de contextualisation. Nous explorons ensuite quelques pistes théoriques et méthodologiques afin de résoudre ce problème. Enfin, nous montrons qu'une telle conception de l'authenticité pourrait aider sur le plan pédagogique, permettant également d'aller au-delà d'un positionnement idéologique restreignant au seul locuteur natif le statut de locuteur « authentique ».

\section{INDEX}

Keywords: authenticity, contextualisation, verbal interaction, native/non-native speaker, ideology, spoken English

Mots-clés: authenticité, contextualisation, interaction orale, locuteur anglophone natif/nonnatif, idéologie, anglais oral

\section{AUTHOR}

\section{ADAM WILSON}

Adam Wilson est actuellement maître de conférences au département de Langues Étrangères Appliquées à l'université de Lorraine et membre du laboratoire de recherche IDEA (EA 2338). Ses recherches portent sur les rapports entre phénomènes sociaux et formes et usages linguistiques dans des contextes sociolinguistiques liés à la globalisation, tels que le tourisme, la migration transnationale, le commerce international et le monde universitaire. Il vise à explorer l'interaction des dynamiques linguistiques et sociales dans ces espaces intenses de multi- et plurilinguisme et de contacts de langues.

adam.wilson@univ-lorraine.fr 